Paper category : Research Paper

\title{
Title: A Structured Catalyst: Noble Metal Supported on a Plate-Type Zirconia Substrate Prepared by Anodic Oxidation for Steam Reforming of Hydrocarbon
}

Authors : Choji Fukuhara ${ }^{a *}$ and Kenji Kawamorita ${ }^{b}$

\author{
a Department of Materials Science and Chemical Engineering, \\ Faculty of Engineering, Shizuoka University, \\ 3-5-1 Johoku, Naka-ku, Hamamatsu, Shizuoka 432-8561, Japan \\ e-mail:tcfukuh@ipc.shizuoka.ac.jp \\ phone:+81-53-478-1171, fax:+81-53-476-0095 \\ b Graduate School of Hachinohe Institute of Technology, \\ 88-1, Myo Ohbiraki, Hachinohe, Aomori 031-8501, Japan
}

* Corresponding author 


\begin{abstract}
A structured catalyst: noble metal supported on a plate-type zirconia substrate was prepared by subjecting a zirconium plate to a process consisting of anodic oxidation in an oxalic acid bath and calcination in the air, followed by rhodium or ruthenium component deposition by the dipping treatment. The catalytic performances of the prepared catalysts were evaluated for steam reforming of n-butane and propane. The substrate surface was significantly corroded by the anodic oxidation and calcination, and a rugged zirconia layer about $100 \mu \mathrm{m}$ thick was formed. The crystalline state of zirconia was mainly monoclinic and tetragonal. In steam reforming of n-butane, the structured ruthenium catalyst had some activity, while the activity of the rhodium catalyst exceeded that of the commercial catalyst. For the rhodium catalyst, its reforming activity was improved by changing the temperature of dipping bath and the number of dips for adjustment of the rhodium deposition state. The rhodium catalyst prepared by dipping twice at a bath temperature of $25^{\circ} \mathrm{C}$ has the largest metal surface area and a higher metal dispersion, which were thought to be the causes for the high performance. In steam reforming of propane, the rhodium catalyst showed a significantly higher activity than the commercial catalyst. The rhodium catalyst was less prone to deterioration of activity due to n-butane and propane reforming.
\end{abstract}

Keywords : Structured catalyst; Noble metal catalyst; Zirconia support; Anodic oxidation; Steam reforming of hydrocarbon 


\section{Introduction}

The steam reforming of hydrocarbon is a reaction that involves a large amount of endothermic energy. Thus, the reformer is required to reduce the thermal time constant and to efficiently supply thermal energy to the reaction zone. By adjusting the reformer to on-board type and portable type, one can deploy the fuel cell power generation system over a wider area, so the reformer is required to be compact and capable of rapid response to load fluctuation. A fixed-bed reactor has usually been used as the reaction system of the reformer. In this type of reformer, a film resistance existed near the reactor wall and a convectional heat transfer in the catalyst bed caused a large temperature gradient inside of the reactor. These factors hinder efficient supply of thermal energy. In addition, the granular catalyst packed in the reactor causes a pressure loss in the catalyst bed, incurring restrictions on reformer response to load fluctuation. To resolve these problems, one must develop a reformer that employs a new reaction system.

A wall-type reactor system, in which a metallic wall is directly catalyzed, is a reaction system that enables an efficient exchange of thermal energy by conductional heat transfer, a rapid response to load fluctuation by a lower pressure loss, and a downsizing of the reactor dimension. We have previously estimated by numerical simulation that the wall-type reactor system will demonstrate such performance even when a reaction is caused with a large amount of reaction energy and/or with a rapid change of feed rate [1-3]. For a methanol decomposition involving a relatively large endothermic energy, we prepared a structured nickel-based catalyst by electroless plating and we constructed a wall-type reactor equipped with such structured catalyst [4-6]. Using this reactor, we verified by experiments that the system actually behaved as estimated by numerical simulation for performance of heat transfer and response to load fluctuation. If a steam reformer for hydrocarbon can be constructed using such a wall-type reaction system, it can be expected that the aforementioned problems with a fixed-bed type reformer will be resolved and that a substantial improvement of the hydrogen generator may be achieved.

For the catalysts for steam reforming of hydrocarbon, development has long been conducted around nickel-based component [7-15], and in the industrial area, 
catalysts of nickel supported on an $\mathrm{Al}_{2} \mathrm{O}_{3}$ support and their improved versions are mainly used. Recently, however, supported metal catalysts using $\mathrm{ZrO}_{2}$ as the support have attracted attention due to their high reforming characteristics and the number of reports on them has increased. Igarashi et al. [16-18] investigated noble metal catalysts supported on $\mathrm{ZrO}_{2}$ and reported that supported rhodium and ruthenium catalysts have high activity in steam reforming of n-butane. According to their inference, the cause is that the water molecules on $\mathrm{ZrO}_{2}$ are activated and thus the formed surface hydroxyl groups have high oxidation activity. Matsumura et al. [19] reported that, among the nickel-based catalysts supported on $\mathrm{ZrO}_{2}, \mathrm{Al}_{2} \mathrm{O}_{3}$, and $\mathrm{SiO}_{2}$ supports, the $\mathrm{Ni} / \mathrm{ZrO}_{2}$ catalyst is the highest in steam reforming of methane. Laosiripojana et al. [20-22] and Dong et al. $[23,24]$ showed that a nickel catalyst deposited on a cerium-added $\mathrm{ZrO}_{2}$ support shifts the steam reforming temperature of methane to a lower temperature range than that on an $\mathrm{Al}_{2} \mathrm{O}_{3}$ support, and suppresses the coke deposition so that the activity is only slightly degraded. Catalysts on $\mathrm{ZrO}_{2}$ support have attractive characteristics. The $\mathrm{ZrO}_{2}$ supports reported so far are available only in granular form. If it is possible to make a zirconia support in a structured form such as a plate-type form and to deposit a reactive metal component on it, such a catalyst will add a reforming system that achieves effective integration of catalytic chemistry and reaction engineering. A new development of the reforming process may be expected.

In this study, using a zirconium plate which has good workability and heat transfer, we prepared a structured catalyst with a noble metal supported on a plate-type zirconia substrate by subjecting a zirconium plate to a process consisting of anodic oxidation, calcination, and dipping treatment of rhodium and/or ruthenium component. Then the prepared structured catalyst was examined to determine its steam reforming characteristics of n-butane and propane. The physicochemical properties of the prepared catalyst were also measured to investigate the structure of catalyst-layer and the supported state of the metal component. In addition, the catalyst preparation conditions were changed to examine the effect of such changes on reforming performance and physicochemical properties of the catalyst.

\section{Experimental}




\subsection{Preparation of plate-type zirconia support and catalyst}

Figure 1 shows the procedure of preparing a structured catalyst with a noble metal supported on a plate-type zirconia substrate. The procedure consists of preparation of a zirconia support, which is the plate-type substrate, and deposition of a metal component on the support by the dipping treatment. The zirconia support was prepared by combining anodic oxidation and calcination of a zirconium plate. In anodizing a zirconium plate, we used a batch-type electrolytic vessel and a constant-current generator, as shown in Figure 2. The electrolytic vessel was placed in a thermostatic water bath to keep it at a constant temperature. First, the surfaces of a zirconium plate (purity $99.7 \%$, t0.5mm, 20x35mm) used as the anode and a copper plate (purity $99.96 \%$, t0.38mm, $20 \times 35 \mathrm{~mm}$ ) used as the cathode were washed in an alkali and an acid solution. They were then set in the electrolyzer with a plate spacing of about $10 \mathrm{~mm}$. Then, an electrolysis current of $150 \mathrm{~mA}$ (a voltage of 120-150V) was supplied from the constant-current generator for 4hours while the electrolyte (about $390 \mathrm{ml}$ ) was stirred at a constant speed. The electrolytic bath was an oxalic acid-type $\left((\mathrm{COOH})_{2} \cdot 2 \mathrm{H}_{2} \mathrm{O}: 2.7\right.$ mol/l, $\mathrm{C}_{6} \mathrm{H}_{8} \mathrm{O}_{7}$ (citric acid): $0.25 \mathrm{~mol} / 1, \mathrm{C}_{3} \mathrm{H}_{8} \mathrm{O}_{3}$ (glycerin): $6.2 \mathrm{~mol} / 1, \mathrm{C}_{2} \mathrm{H}_{5} \mathrm{OH}: 25.1$ $\mathrm{mol} / \mathrm{l}$ ) and the bath temperature was $60{ }^{\circ} \mathrm{C}$. After being washed in a water bath, the zirconium plate was calcined in an electric furnace to accelerate the oxidation of the plate surface. The calcination conditions were: a temperature of $900{ }^{\circ} \mathrm{C}$ (and/or $880{ }^{\circ} \mathrm{C}$ ), a heat-up time of $3 \mathrm{~h}$, and a holding time of $1 \mathrm{~h}$. The electrolytic treatment and calcination were repeated twice. Supporting the metal component on the zirconium substrate was done by the dipping treatment, that is, by immersing the substrate in a bath of aqueous solution of a rhodium precursor $\left(\mathrm{RhCl}_{3} \cdot \mathrm{H}_{2} \mathrm{O}: 1.52 \times 10^{-3} \mathrm{~mol} / \mathrm{l}, \mathrm{pH}: 6.7\right)$ and a ruthenium precursor $\left(\mathrm{RuCl}_{3} \cdot 3 \mathrm{H}_{2} \mathrm{O}: 1.52 \times 10^{-3} \mathrm{~mol} / 1, \mathrm{NH}_{2} \mathrm{CH}_{2} \mathrm{CH}_{2} \mathrm{NH}_{2}: 6.0 \times 10^{-2}\right.$ $\left.\mathrm{mol} / \mathrm{l}, \mathrm{S}\left(\mathrm{CH}_{2} \mathrm{COOH}\right)_{2}: 1.3 \times 10^{-3} \mathrm{~mol} / \mathrm{l}, \mathrm{pH}: 11.3\right)$. On completion of the electrolytic treatment and calcination, the substrate was immersed in each metal bath at a temperature of $25-40{ }^{\circ} \mathrm{C}$ for $24 \mathrm{~h}$ while stirring the bath calmly and while controlling the $\mathrm{pH}$ to a constant value. After the dip, the substrate was calcined at $500{ }^{\circ} \mathrm{C}$. The dipping treatment and calcination were performed once or twice.

\subsection{Steam reforming of hydrocarbon over the structured catalyst}

The steam reforming of hydrocarbon over the prepared structured catalyst was 
conducted at atmospheric pressure using a conventional flow reactor. After being placed in the reactor, the prepared catalyst was reduced in a hydrogen stream $(100 \mathrm{ml} / \mathrm{min})$ at $500{ }^{\circ} \mathrm{C}$ for $2 \mathrm{~h}$. Two pieces of catalyst were loaded in the reactor. The hydrocarbon and water were then pumped into the reactor. The hydrocarbons as raw material were n-butane and propane. The flow rate of n-butane was $7.0 \times 10^{-4} \mathrm{~mol} / \mathrm{min}$ and propane $9.3 \times 10^{-4} \mathrm{~mol} / \mathrm{min}$. The partial pressure of feed was $1.0 \mathrm{~atm}$, the ratio of steam to carbon (S/C) was 3.0. Thus, the space velocity (GHSV based on the net volume of the catalyst layer formed by anodic oxidation and calcination) was $43,000 \mathrm{~h}^{-1}$ for $\mathrm{n}$-butane reforming and $44,000 \mathrm{~h}^{-1}$ for propane reforming. The reaction temperature was 350-600 ${ }^{\circ} \mathrm{C}$. Conversion and selectivity of product were calculated on the basis of carbon. The performance data for the catalyst was collected one hour after the start of reforming, except for the durability performance test.

For comparison with the structured catalyst, reforming performances of commercial granular catalysts (SÜD-CHEMIE, FCR-4-02L (based $\mathrm{Ni} / \mathrm{Al}_{2} \mathrm{O}_{3}$ ) and RUA (based $\mathrm{Ru} / \mathrm{Al}_{2} \mathrm{O}_{3}$ ), $\Phi 0.5-1.0 \mathrm{~mm}$ ) were investigated under the same reaction conditions as the structured catalyst. The packed amount of the granular catalyst was $0.28 \mathrm{~g}$, which made the packed volume of the granular catalyst equal to the net volume of catalytic layer formed by anodic oxidation and calcination on the structured catalyst.

\subsection{Characterization of formed layer}

The physicochemical properties of the prepared catalyst were characterized using some instruments for analysis. The surface morphology and the sectional view of the formed layer were observed using SEM (HITACHI S-4300), and the elemental profiles in the same field were analyzed using EDX (HORIBA EMAX-7000). The crystal structure for a layer formed on the catalyst was measured using XRD (RIGAKU RINT2000/PC) with $\mathrm{CuK} \alpha$ radiation. The surface area of the prepared catalyst was measured by the BET method (COULTER SA3100-PLUS) using nitrogen at its boiling point. Using the catalyst sample after depositing noble metal component, we examined the supported state of noble metal component by measuring the amount of pulse adsorption of carbon monoxide (BEL Japan BEL-CAT). Before the measurement, the sample was reduced $\left(500{ }^{\circ} \mathrm{C}\right.$, hydrogen stream: $\left.100 \mathrm{ml} / \mathrm{min}, 2 \mathrm{~h}\right)$ and then a constant amount of carbon monoxide (concentration: $5 \%$, helium balance) was pulse-injected at 
a constant temperature of $35^{\circ} \mathrm{C}$ for 5 -minute intervals. The amount of one pulse volume was $0.086 \mathrm{ml}$. The surface area and the mean particle size of metal components were estimated from the obtained data.

\section{Results and discussion}

\subsection{Morphology of formed catalytic layer on the substrate}

Figure 3 shows SEM photographs of the surface and results of elemental analysis measured by EDX at typical points of the prepared structured catalysts. For these catalysts, a zirconium plate was treated by electrolysis for 4 hours and by calcination at $900{ }^{\circ} \mathrm{C}$; this set of operations was repeated twice. Then, the substrate was immersed in a dipping bath of rhodium or ruthenium precursor (for both, the dipping temperature was $25{ }^{\circ} \mathrm{C}$ and the number of dips was one). Figure 4 shows a SEM photograph of a section of the prepared substrate before dipping treatment and the result of elemental analysis measured by EDX on the portion intervening between the two white lines. Figure 5 shows the XRD profile for the surface layer of the substrate shown in Figure 4. In Figure 3, a large crack is observed on the surface of both samples, and one can see from the section photograph in Figure 4 that the crack depth is about $50 \mu \mathrm{m}$. The zirconium substrate surface was considerably eroded by the electrolysis treatment and calcination. From the results of elemental analysis of a section, a distribution of oxygen can be confirmed at a depth of about $100 \mu \mathrm{m}$ from the substrate surface. In this portion, additionally, the zirconium profile was found to be smaller than the peak intensity detected from the substrate base. We think that zirconium forms an oxide layer in this portion. In fact, from the XRD profile in Figure 5, many peaks attributable to zirconia were clearly observed. These peaks originate mainly from the monoclinic and tetragonal crystals of zirconia. It can be inferred that a rugged zirconia layer with about $100 \mu \mathrm{m}$ thick is formed on the substrate by subjecting the zirconium substrate to electrolysis treatment and calcination. According to a generally proposed chemical equation for anodizing [25], the reaction on the anode side is thought to proceed as $\mathrm{Zr}+2 \mathrm{H}_{2} \mathrm{O} \rightarrow$ $\mathrm{ZrO}_{2}+4 \mathrm{H}^{+}+4 \mathrm{e}^{-}\left(\mathrm{OH}^{-}\right.$may be involved depending on $\left.\mathrm{pH}\right)$; then the oxidized layer is formed on the substrate. Such an oxidized layer would find its oxidation state accelerated by the calcination process. Figure 6 shows photographs of zirconium 
substrate before treatment and after electrolysis and calcination treatment. After treatment, one can see that the substrate surface appears white, which is peculiar to the zirconia component.

From the EDX analysis results shown in Figure 3, a rhodium component was detected of about $2.6 \mathrm{wt} \%$ in the case of dipping in the rhodium precursor bath, while a ruthenium component of about $0.4 \mathrm{wt} \%$ was detected in the ruthenium precursor bath. It is reported that, on the zirconia support surface, the isoelectric point lies near a $\mathrm{pH}$ of 6.7. In an immersion operation, the charge on the support surface becomes a dominant factor. Therefore, the $\mathrm{pH} 6.7$ of dipping rhodium condition might be one of the factors to deposit a large amount of rhodium component. At any rate, by the preparation method consisting of electrolysis, calcination and dipping of the zirconium substrate, the structured catalysts with a noble metal supported on the plate-type zirconia substrate were successfully prepared. Hereafter, the prepared structured catalysts will be denoted by "plate-type $\mathrm{Rh} / \mathrm{ZrO}_{2}$ catalyst" and "plate-type $\mathrm{Ru} / \mathrm{ZrO}_{2}$ catalyst", respectively.

\subsection{Reforming properties of n-butane for the plate-type $\mathrm{Rh} / \mathrm{ZrO}_{2}$ and $\mathrm{Ru} / \mathrm{ZrO}_{2}$ catalysts}

Figure 7 shows the reforming activity of n-butane over the prepared plate-type $\mathrm{Rh} / \mathrm{ZrO}_{2}$ and $\mathrm{Ru} / \mathrm{ZrO}_{2}$ catalysts, and Figure 8 shows the selectivity of product over these catalysts. In Figure 7, the performances of a commercial granular FCR-4-02L (based $\mathrm{Ni} / \mathrm{Al}_{2} \mathrm{O}_{3}$ ) catalyst and granular $\mathrm{RUA}$ (based $\mathrm{Ru} / \mathrm{Al}_{2} \mathrm{O}_{3}$ ) catalyst under the same reaction condition are shown for comparison. From the figure of reforming activity, one can see that the plate-type $\mathrm{Ru} / \mathrm{ZrO}_{2}$ catalyst is higher in activity than the commercial FCR-4-02L catalyst, but lower than the commercial RUA catalyst. On the other hand, the activity of the plate-type $\mathrm{Rh} / \mathrm{ZrO}_{2}$ catalyst is higher than those of the FCR-4-02L and RUA catalysts. It was found that the prepared plate-type catalysts showed a relatively high activity for the n-butane reforming, and that the catalyst with the rhodium component shows a higher reforming activity than the commercial granular catalysts. Igarashi et al. [16,17] reported that the surface hydroxyl group formed on $\mathrm{ZrO}_{2}$ have high oxidation performance and improve n-butane reforming activity. Laosiripojana et al. [20, 21] and Roh et al. [24] reported that a zirconia support lowers the methane reforming temperature below that by an alumina support. The results shown in Figure 7 indicate that the high performance of such a zirconia support is 
expressed in the prepared structured catalyst as well. From Figure 8, one can see that these catalysts showed about the same tendency as to the selectivity of product. That is, at lower temperatures, a large amount of the byproduct $\mathrm{CH}_{4}$ is formed as well as the main product $\mathrm{CO}_{2}$; however, its amount decreases with increasing temperature and the amount of $\mathrm{CO}$ increases instead. At $600{ }^{\circ} \mathrm{C}$, the $\mathrm{CO}$ selectivity is close to the $\mathrm{CO}_{2}$ selectivity. Thus, the difference of metal species does not have a large influence on the selectivity of product.

Figure 9 shows reforming activity of the plate-type $\mathrm{Rh} / \mathrm{ZrO}_{2}$ catalyst, which was prepared using a zirconium substrate calcining temperature of $880{ }^{\circ} \mathrm{C}$ but otherwise under the same preparation conditions. In this figure, a substantial decrease in reforming activity of the catalyst is recognized compared to the case of calcining at $900{ }^{\circ} \mathrm{C}$. According to a visual observation of the catalyst surface, the degree of white layer formation on the surface, as shown in Figure 6, is lower than the degree for that treated at $900{ }^{\circ} \mathrm{C}$. In the calcination process, one hour holding time was adopted at each calcining temperature. Thus the formation of the zirconia layer calcined at $880{ }^{\circ} \mathrm{C}$ was somewhat insufficient because of a short holding time. Such insufficiency in zirconia layer formation was thought to be a cause of the activity degradation. When the calcining temperature was changed over $900{ }^{\circ} \mathrm{C}$, the activity did not change. Moreover, since electrolysis time is thought to be an important parameter as well as calcining temperature, it was examined and we confirmed that the optimum electrolysis time of one operation is 4 hours.

In the rhodium component deposition process, the bath temperature and the number of dips would be thought to have some effect on a deposited state of rhodium component, because they could change physical and chemical driving forces of metal deposition. Thus, such parameters were changed to investigate the effect of them on the reforming activity of the plate-type catalyst. The obtained result is shown in Figure 10. The preparation condition of the zirconia layer was the same as the case of Figure 7. The figure shows that increasing the bath temperature progresses the reforming activity. Even at a bath temperature of $25^{\circ} \mathrm{C}$, the sample dipped twice shows the highest activity of the catalysts prepared in this study. Table 1 represents analysis results for supported state of rhodium component on the various catalysts shown in Figure 10. As contrasted with the activity of the single-dipped catalyst, the surface area of rhodium metal 
increases with increasing bath temperature, that is, there is a correspondence with the increase in activity. However, the catalyst prepared at a bath temperature of $40{ }^{\circ} \mathrm{C}$ has a rather large particle size, so the degree of metal dispersion is low. Its activity is high because a large amount of rhodium was deposited, while the state of rhodium supported on the catalyst is not good. A SEM observation shows rhodium particles in the agglomerated state on this catalyst. The catalyst dipped twice at a bath temperature of $25{ }^{\circ} \mathrm{C}$ has the largest metal surface area and its mean particle size is smaller. The degree of metal dispersion is also higher. Such supported state of rhodium component might be one of the causes of the higher reforming activity. With regard to the product selectivity, no large difference in these catalysts can be seen from Figure 8. Namely, besides the main product of $\mathrm{CO}_{2}$, a large amount of $\mathrm{CH}_{4}$ was formed as a byproduct at low temperatures. Its amount decreased with increasing temperature and the amount of $\mathrm{CO}$ increased instead.

\subsection{Reforming property of propane for the plate-type $\mathrm{Rh} / \mathrm{ZrO}_{2}$ catalyst}

Figure 11 shows the propane reforming property of the plate-type $\mathrm{Rh} / \mathrm{ZrO}{ }_{2}$ catalysts, these were prepared at a substrate calcining temperature of $900{ }^{\circ} \mathrm{C}$ and by dipping once in the rhodium precursor bath $\left(25^{\circ} \mathrm{C}\right)$. For comparison, the reforming activities of granular FCR-4-02L and RUA catalysts are shown under the same reaction conditions. In the figure, the plate-type $\mathrm{Rh} / \mathrm{ZrO}_{2}$ catalyst shows a rather high propane reforming activity and exceeds by far in performance of the commercial granular FCR-4-02L and RUA catalysts. Such high performance of the plate-type $\mathrm{Rh} / \mathrm{ZrO}_{2}$ catalyst was also demonstrated in n-butane reforming, as shown in Figure 7. Igarashi et al. [17] inferred that the steam reforming of hydrocarbon on a zirconia-supported noble metal catalyst proceeds by the Langmuir-Hinshelwood mechanism, in which water molecules were activated on zirconia support and hydrocarbons were activated on the noble metal. Considering this reaction mechanism, we consider that there might be a different reactivity for the adsorbed species between that on the prepared $\mathrm{Rh} / \mathrm{ZrO} 2$ catalyst and that on commercial granular catalysts. To confirm such difference, one should investigate the adsorbed state of chemical species on these catalysts by means of spectroscopic analysis. The product selectivity of the $\mathrm{Rh} / \mathrm{ZrO}_{2}$ catalyst was about the same as for n-butane reforming. That is, besides the main product of $\mathrm{CO}_{2}$, much $\mathrm{CH}_{4}$ 
was formed at lower temperature and much $\mathrm{CO}$ at higher temperature.

Figure 12 shows the reforming activity of propane for a plate-type $\mathrm{Rh} / \mathrm{ZrO}_{2}$ catalyst prepared by dipping twice in a rhodium precursor bath $\left(25^{\circ} \mathrm{C}\right)$. In this experiment, the temperature was taken lower than the results shown in Figure 11. In the figure, the prepared catalyst shows high activity from $350{ }^{\circ} \mathrm{C}$ upward. In comparison, at $450-500{ }^{\circ} \mathrm{C}$, the activity is higher than that of a catalyst prepared by dipping once in the rhodium precursor bath. Its activity seems to be close to the equilibrium conversion. As with n-butane reforming, the activity increases with an increasing number of dippings. It is conceivably possible for propane reforming as well to prepare a structured catalyst having high catalytic performance by more-finely controlling the deposition condition of rhodium. The selectivity did not much differ from that of the catalyst prepared by dipping once.

\subsection{Durability performance of the plate-type $\mathrm{Rh} / \mathrm{ZrO}_{2}$ catalyst}

Figure 13 shows durability reforming performance of the plate-type $\mathrm{Rh} / \mathrm{ZrO}_{2}$ catalyst, which was prepared by calcining the substrate at a temperature of $900{ }^{\circ} \mathrm{C}$ and dipping twice in the rhodium precursor bath at a temperature of $25{ }^{\circ} \mathrm{C}$. The reaction temperature was $500{ }^{\circ} \mathrm{C}$. For comparison, Figure 13(a) also shows durability performance under the same reaction condition of the catalyst prepared by dipping once at a bath temperature of $35^{\circ} \mathrm{C}$. In the figure, the activity of the catalyst prepared by dipping once gradually declines from the start of the reaction, and after $10 \mathrm{~h}$, an activity deterioration of about $25 \%$ is shown. One conceivable cause of this deterioration is coke deposition accompanying the reaction. In fact, an observation on the catalyst surface after the reaction found such coke deposition. On the other hand, for the catalyst prepared by dipping twice in a bath at $25^{\circ} \mathrm{C}$, the degree of deterioration is low. This tendency is the same as that with propane reforming. On the catalyst surface after the reactions, little coke deposition was observed after any reaction. If industrial uses are assumed, it will be necessary to evaluate this catalyst as to its durability performance over a longer period. Judging from Figure 13, however, one can conclude that this catalyst could be quite promising for stable performance if a third component for restraining the deterioration is added. 


\section{Conclusion}

The structured catalysts: noble metal supported on the plate-type zirconia substrate were successfully prepared by means of anodic oxidation and calcination of the zirconium plate, followed by dipping treatment of rhodium and ruthenium components. The corroded surface and the rugged layer of zirconia about $100 \mu \mathrm{m}$ thick were formed on the zirconium plate. In n-butane reforming, the prepared plate-type $\mathrm{Ru} / \mathrm{ZrO}_{2}$ catalyst had some activity, while the activity of the $\mathrm{Rh} / \mathrm{ZrO}_{2}$ catalyst exceeded that of the commercial catalyst. The $\mathrm{Rh} / \mathrm{ZrO}_{2}$ catalyst also showed a high activity in propane reforming. The reforming activity of the $\mathrm{Rh} / \mathrm{ZrO}_{2}$ catalyst was improved by changing the temperature of dipping bath and the number of dips. The prepared $\mathrm{Rh} / \mathrm{ZrO} \mathrm{O}_{2}$ catalyst was less prone to deterioration of reforming activity.

\section{References}

[1] C. Fukuhara, A. Igarashi, Kagaku Kogaku Ronbunshu, 19 (1993) 295-302.

[2] C. Fukuhara, A. Igarashi, J. Jpn. Petrol. Inst., 38 (1995) 88-96.

[3] C. Fukuhara, A. Igarashi, Chem. Eng. Sci., 60 (2005) 6824-6834.

[4] C. Fukuhara, A. Igarashi, J. Chem. Eng. Jpn., 36 (2003) 730-734.

[5] C. Fukuhara, A. Igarashi, J. Chem. Eng. Jpn., 37 (2004) 23-30.

[6] C. Fukuhara, A. Igarashi, J. Chem. Eng. Jpn., 37 (2004) 415-421.

[7] J. R. Rostrup-Nielsen, J. Catal., 31 (1973) 173-199.

[8] J. R. Rostrup-Nielsen, J. Catal., 33 (1974) 184-201.

[9] T. Borowiecki, Appl. Catal., 10 (1984) 273-289.

[10] T. Borowiecki, Appl. Catal., 31 (1987) 207-220.

[11] Q. Zhuang, Y. Qin, L. Chang, Appl. Catal., 70 (1991) 1-8.

[12] T. Borowiecki, G. Giecko, M. Panczyk, Appl. Catal. A: Gen., 230 (2002) 85-97.

[13] P.A.A. Adesina, D.L. Trimm, N.W. Cant, Chem. Eng. J., 99 (2004) 131-136.

[14] K.M. Hardiman, T.T. Ying, A.A. Adesina, E.M. Kennedy, B.Z. Dlugogorski, Chem. Eng. J., 102 (2004) 119-130.

[15] C. Pistonesi, A. Juan, B. Irigoyen, N. Amadeo, Appl. Sur. Sci., 253 (2007) 4427-4437.

[16] A. Igarashi, T. Ohtaka, S. Motoki, Catal. Lett., 13 (1991) 189-194. 
[17] A. Igarashi, T. Ohtaka, T. Honma, C. Fukuhara, Stud. Surf. Sci. Catal., 75 (1992) 2083-2086.

[18] A. Igarashi, T. Sakata, M. Matsuzawa, C. Fukuhara, J. Jpn. Petrol. Inst., 35 (1992) 490-493.

[19] Y. Matsumura, T. Nakamori, Appl. Catal. A: Gen., 258 (2004) 107-114.

[20] N. Laosiripojana, S. Assabumrungrat, Appl. Catal. A: Gen., 290 (2005) 200-211.

[21] N. Laosiripojana, D. Chadwick, S. Assabumrungrat, Chem. Eng. J., 138 (2008) 264-273.

[22] N. Laosiripojana, S. Assabumrungrat, J. Power Sources, 158 (2006) 1348-1357.

[23] W-S. Dong, H-S. Roh, K-W. Jun, S-E. Park, Y-S. Oh, Appl. Catal. A: Gen., 226 (2002) 63-72.

[24] H-S. Roh, K-W. Jun, W-S Dong, J-S. Chang, S-E. Park, Y-I. Joe, J. Mol. Catal. A: Chem., 181 (2002) 137-142.

[25] N. Baba. (Eds.), Oxidized Films Prepared by Electrolytic Treatment (in Japanese), Maki-Syoten, Tokyo, 1996, pp.3-8. 


\section{Caption to figures}

Fig.1 Preparation procedure of a structured catalyst: noble metal supported on a plate-type zirconia substrate.

Fig.2 Schematic diagram of electrolysis apparatus.

Fig.3 SEM photographs of the substrate surface dipped in (a) rhodium and (b) ruthenium precursor baths.

Fig.4 (a) SEM photograph and (b) elemental profile measured by EDX for sections of the layer formed on substrate before dipping treatment.

Fig.5 XRD profile for the surface layer formed on zirconium substrate after anodic oxidation and calcination.

Fig.6 Photographs of zirconium substrate (a) before and (b) after treatment.

Fig.7 Reforming activities of n-butane for the plate-type $\mathrm{Rh} / \mathrm{ZrO}{ }_{2}$ and $\mathrm{Ru} / \mathrm{ZrO}_{2}$ catalysts prepared on zirconia support.

Fig.8 Reforming selectivities of n-butane for the plate-type (a) $\mathrm{Rh} / \mathrm{ZrO}_{2}$ and (b) $\mathrm{Ru} / \mathrm{ZrO}_{2}$ catalysts.

Fig.9 Effect of calcination temperature of zirconium substrate on the reforming activity for the plate-type $\mathrm{Rh} / \mathrm{ZrO}_{2}$ catalyst.

Fig.10 Effect of dipping condition of rhodium component on the n-butane reforming activity for the plate-type $\mathrm{Rh} / \mathrm{ZrO}_{2}$ catalyst.

Fig. 11 (a) Catalytic activity and (b) selectivity of the plate-type $\mathrm{Rh} / \mathrm{ZrO}_{2}$ catalyst for steam reforming of propane.

Fig. 12 Reforming activity of propane for the plate-type $\mathrm{Rh} / \mathrm{ZrO}_{2}$ catalysts prepared by twice-dipping treatment.

Fig.13 Durability performance of the plate-type $\mathrm{Rh} / \mathrm{ZrO}_{2}$ catalyst for steam reforming of (a) n-butane and (b) propane. 


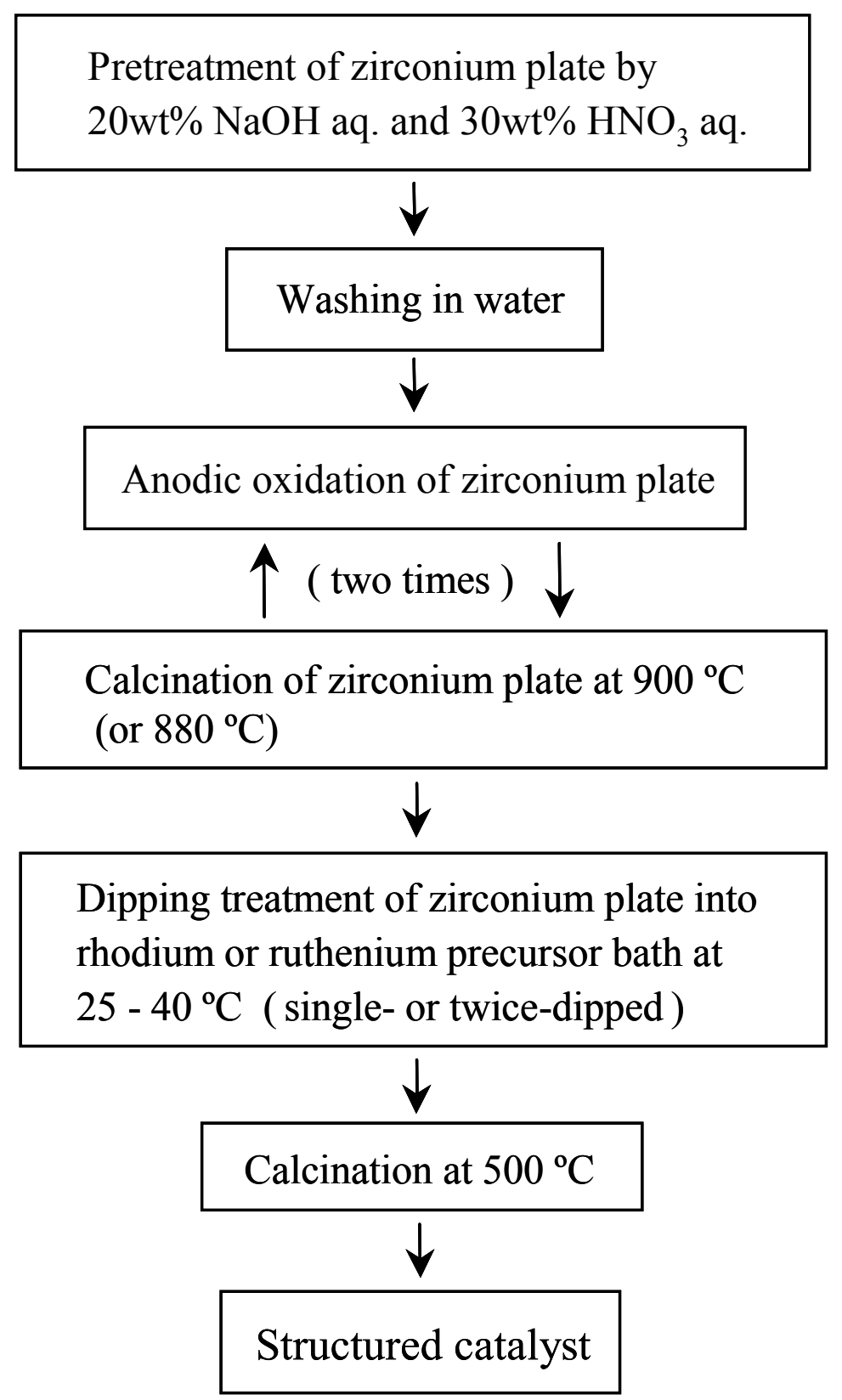

Fig.1 Preparation procedure of a structured catalyst: noble metal supported on a plate-type zirconia substrate. 


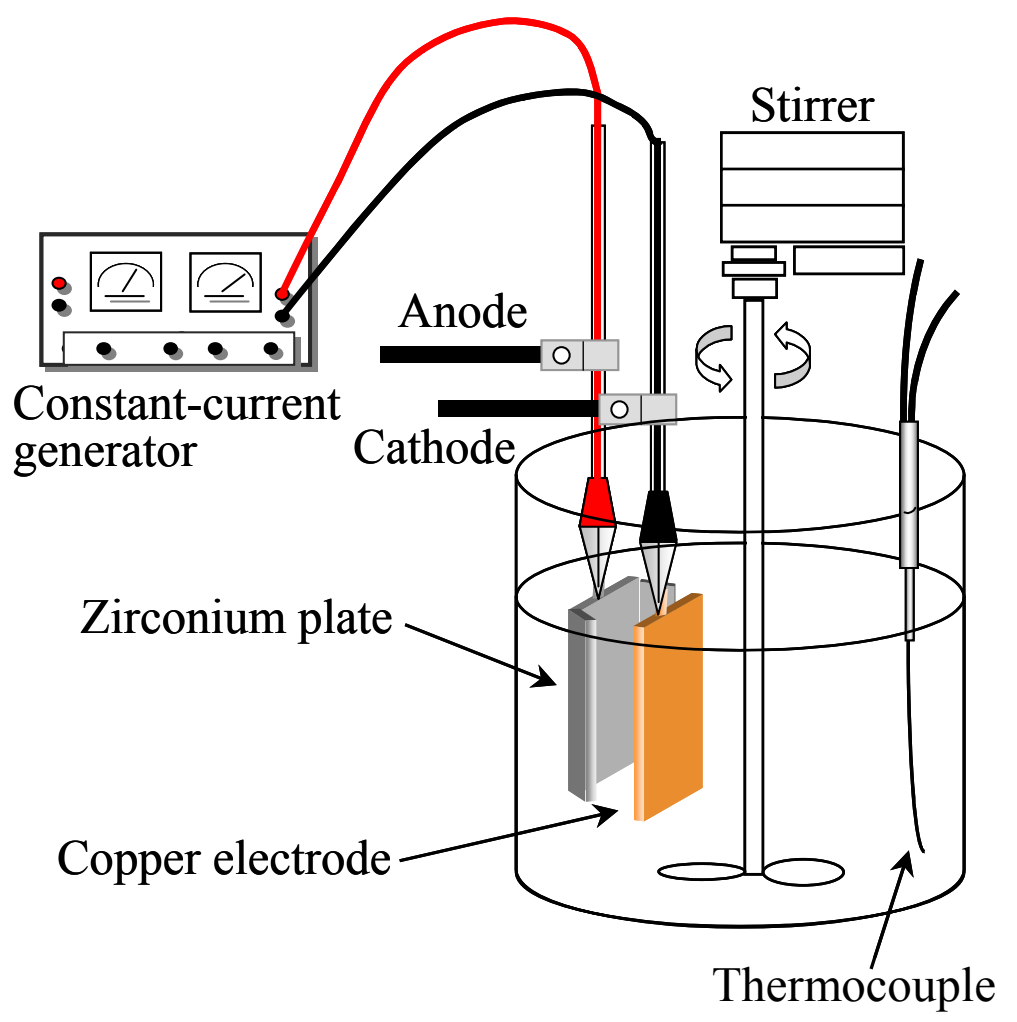

Fig.2 Schematic diagram of electrolysis apparatus. 


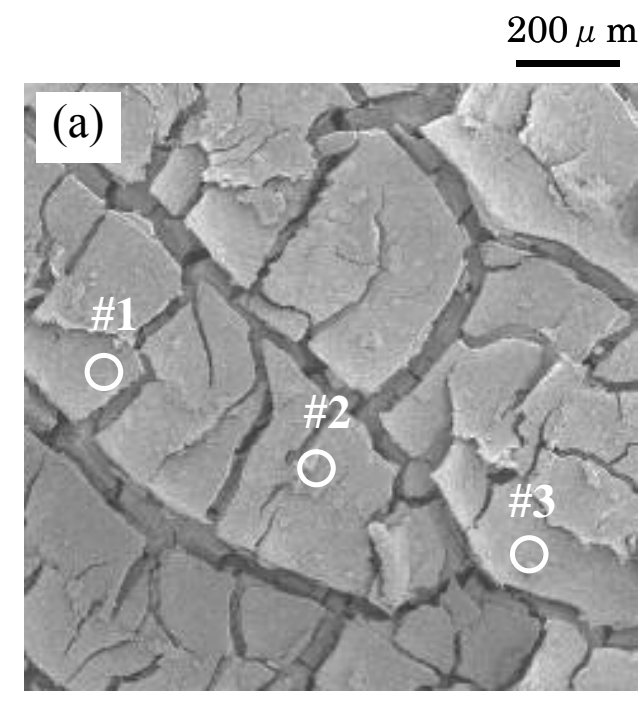

Average element concentrations estimated from \#1, \#2 and \#3

\begin{tabular}{cc}
\hline Element & Concentration (wt\%) \\
\hline $\mathrm{Zr}$ & 97.4 \\
$\mathrm{Rh}$ & 2.6 \\
\hline
\end{tabular}

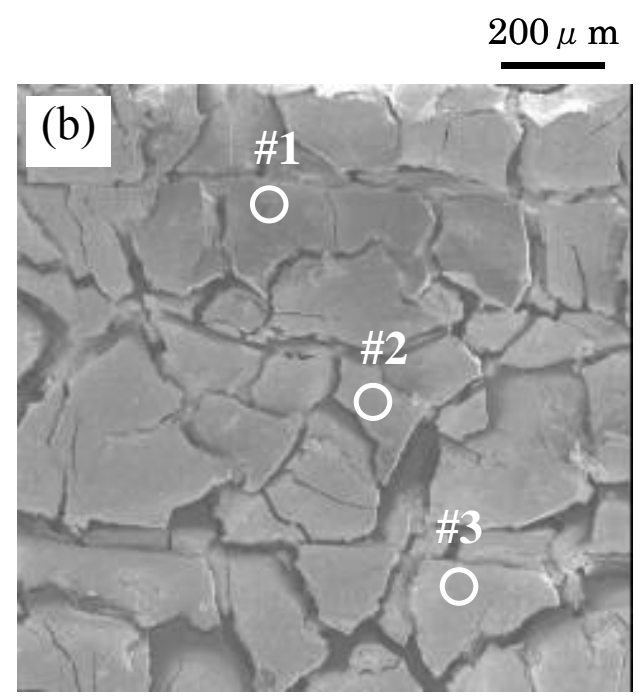

Average element concentrations estimated from \#1, \#2 and \#3

\begin{tabular}{cc}
\hline Element & Concentration (wt\%) \\
\hline $\mathrm{Zr}$ & 99.6 \\
$\mathrm{Ru}$ & 0.4 \\
\hline
\end{tabular}

Fig.3 SEM photographs of the substrate surface dipped in (a) rhodium and (b) ruthenium precursor baths. 


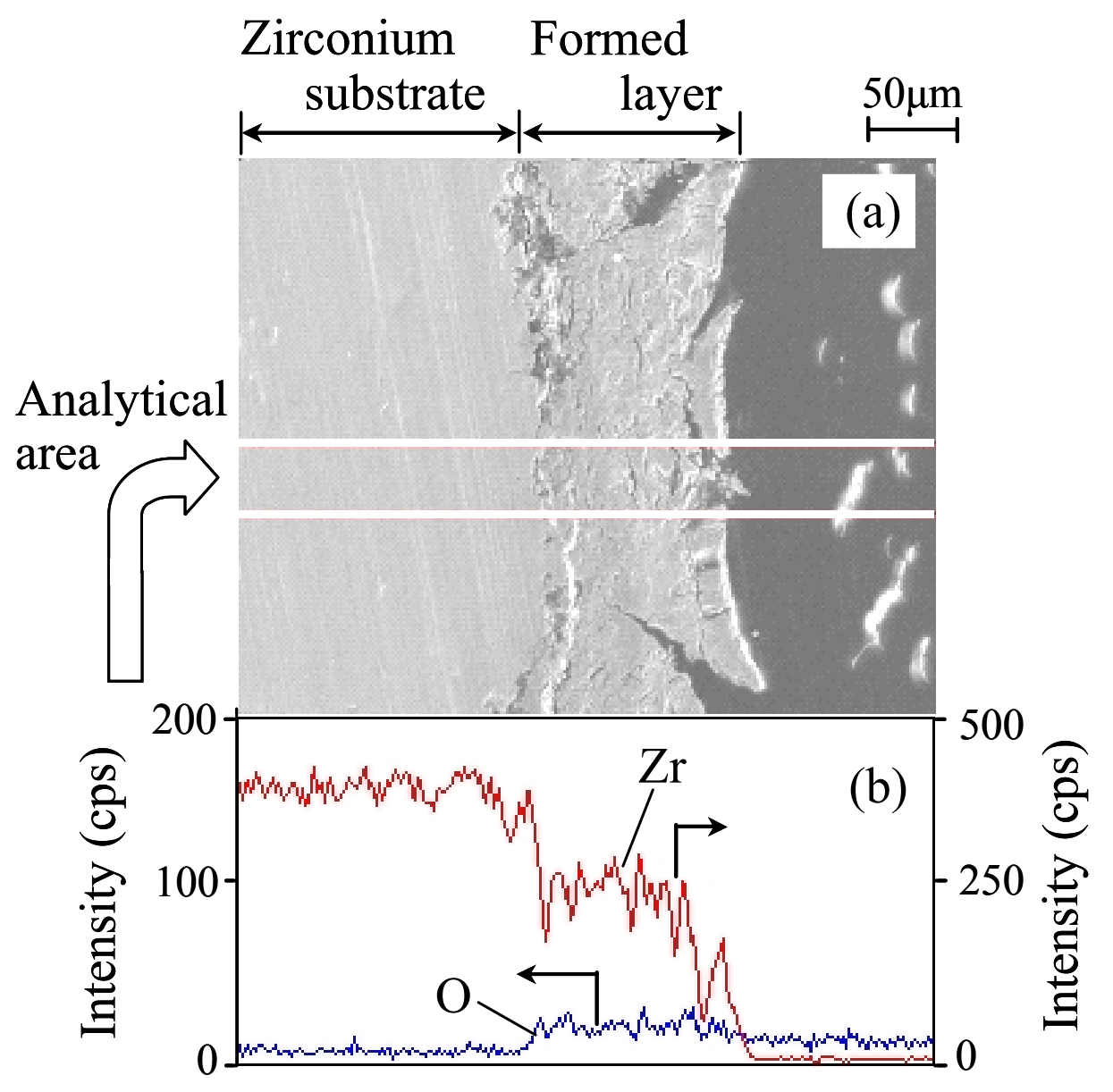

Fig.4 (a) SEM photograph and (b) elemental profile measured by EDX for sections of the layer formed on substrate before dipping treatment. 


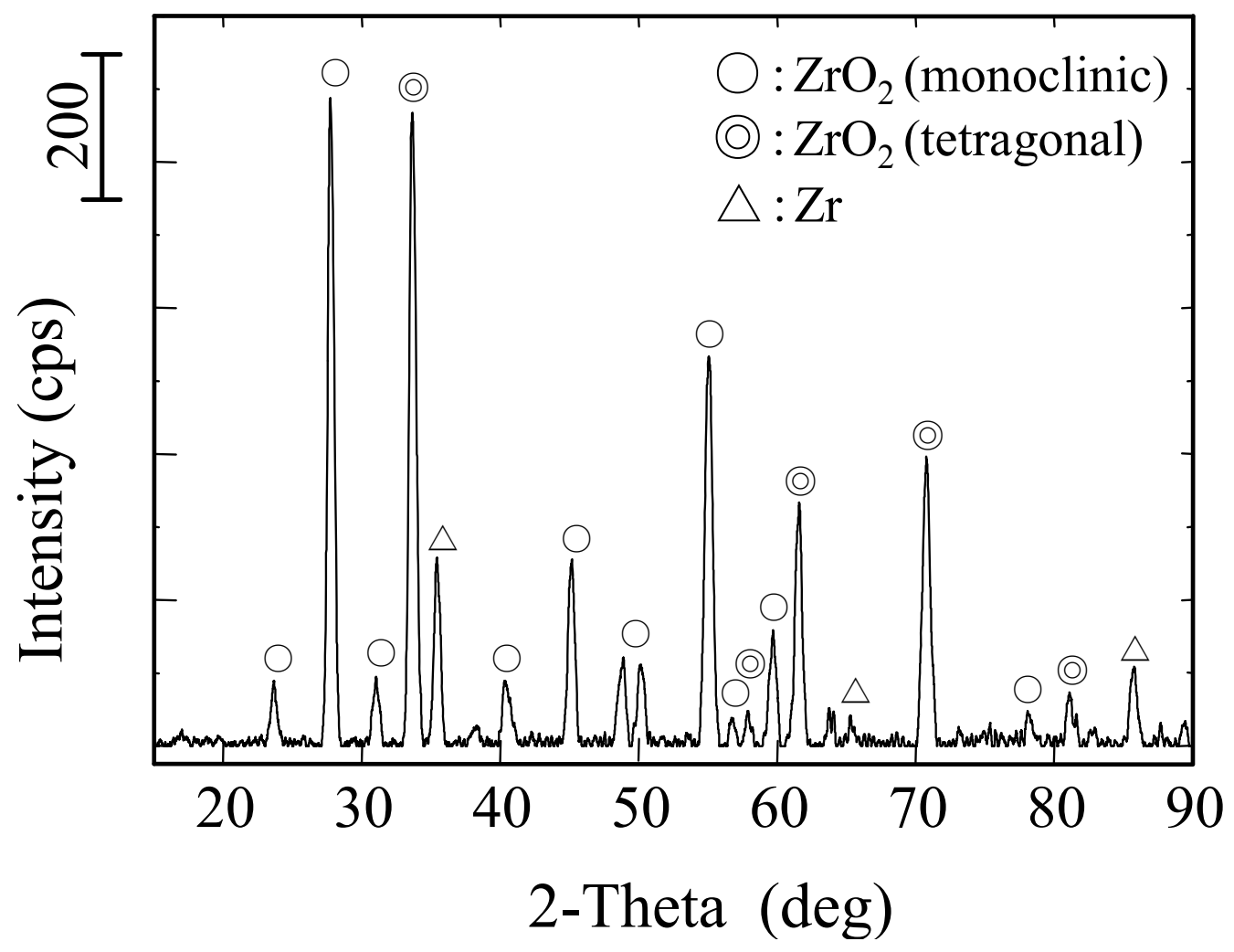

Fig. 5 XRD profile for the surface layer formed on zirconium substrate after anodic oxidation and calcination. 
(a) Before treatment

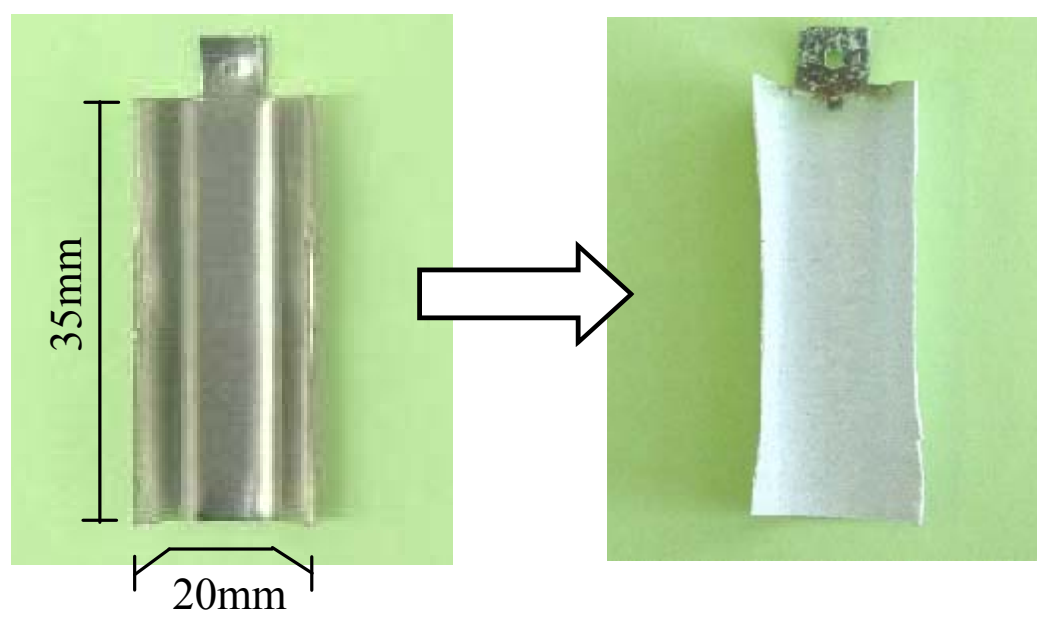

Fig.6 Photographs of zirconium substrate (a) before and (b) after treatment. 


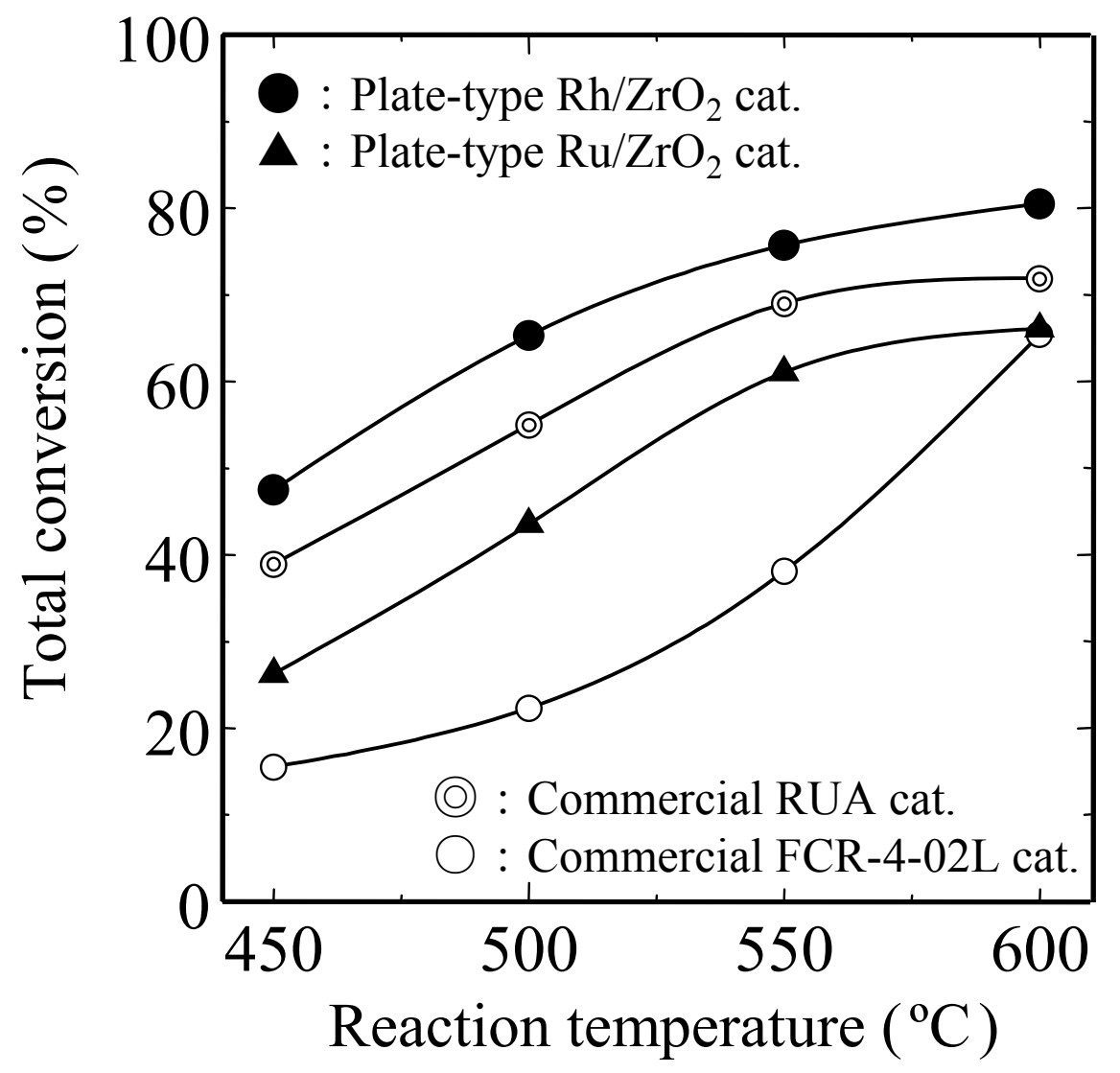

Fig.7 Reforming activities of n-butane for the plate-type $\mathrm{Rh} / \mathrm{ZrO}_{2}$ and $\mathrm{Ru} / \mathrm{ZrO}_{2}$ catalysts prepared on zirconia support. 


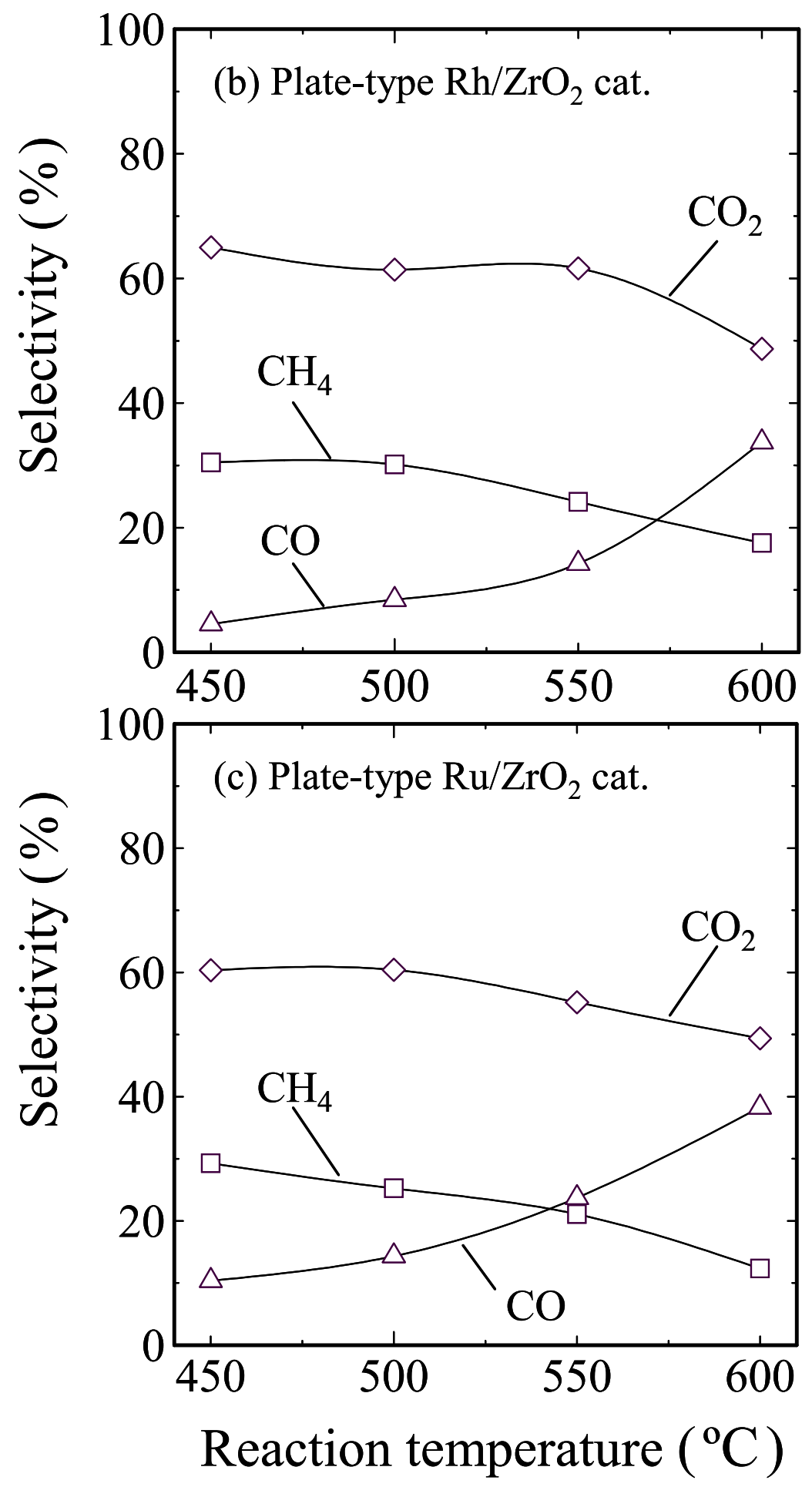

Fig.8 Reforming selectivities of n-butane for the plate-type (a) $\mathrm{Rh} / \mathrm{ZrO}_{2}$ and (b) $\mathrm{Ru} / \mathrm{ZrO}_{2}$ catalysts. 


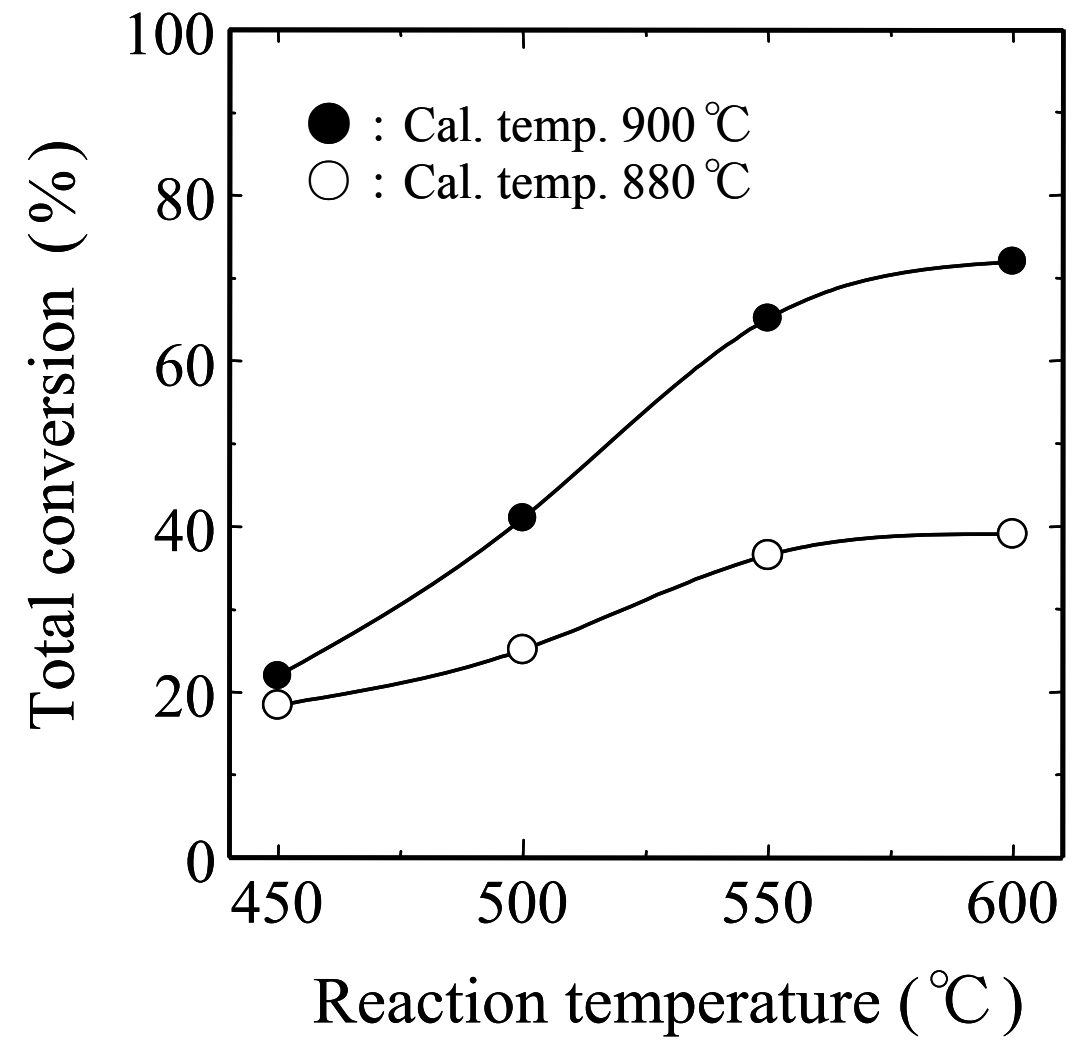

Fig.9 Effect of calcination temperature of zirconium substrate on the reforming activity for the plate-type $\mathrm{Rh} / \mathrm{ZrO}_{2}$ catalyst. 


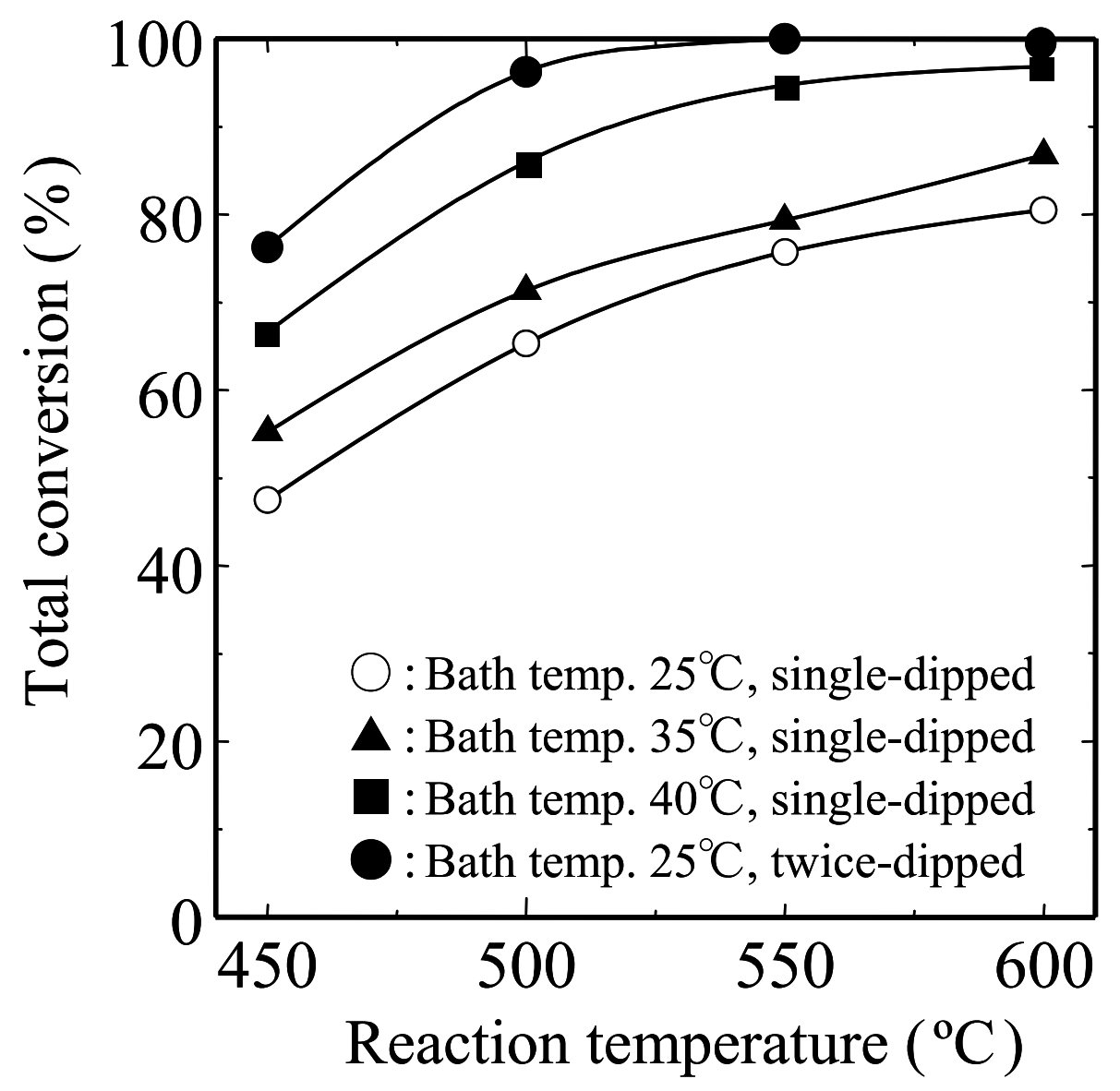

Fig.10 Effect of dipping condition of rhodium component on the n-butane reforming activity for the plate-type $\mathrm{Rh} / \mathrm{ZrO}_{2}$ catalyst. 


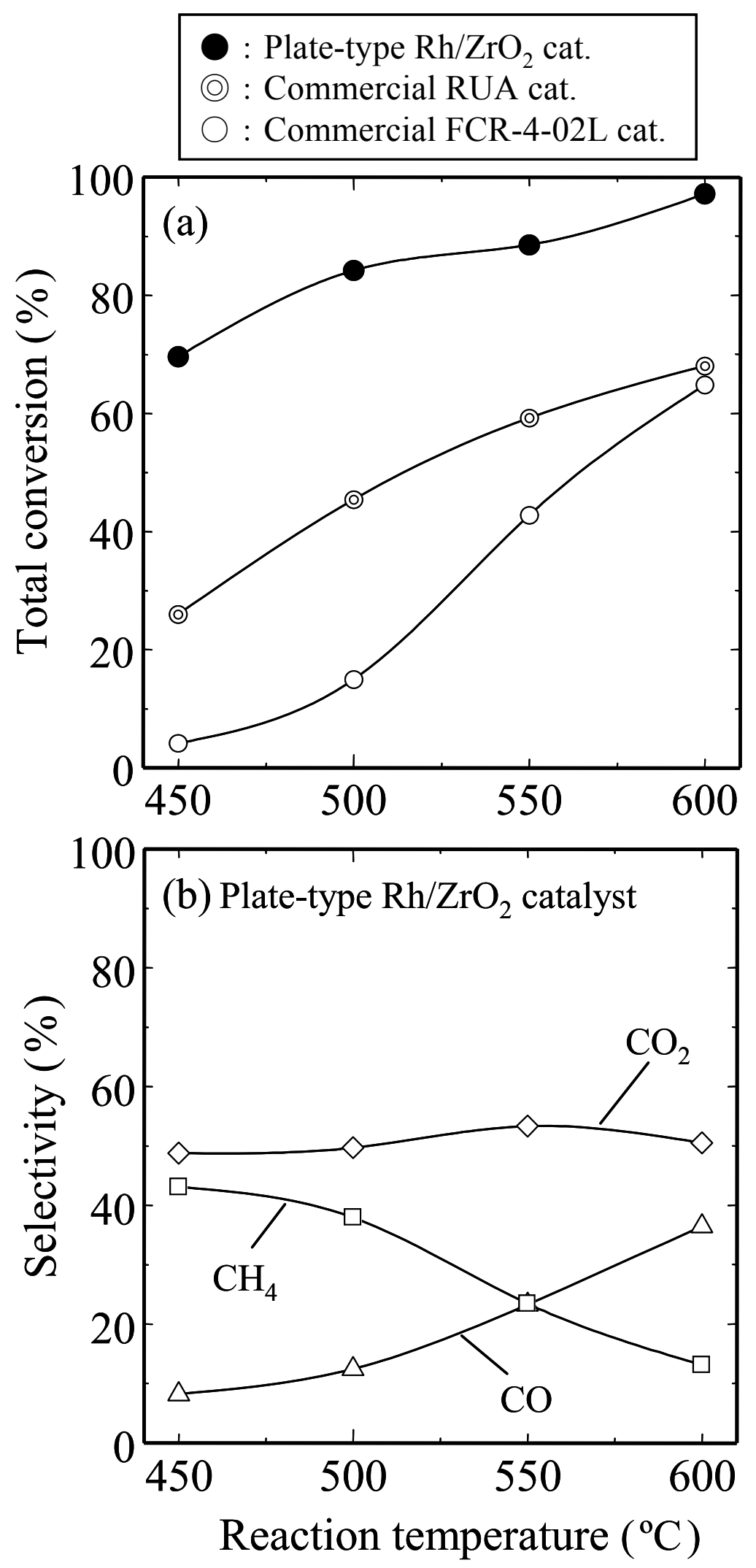

Fig.11 (a) Catalytic activity and (b) selectivity of the plate-type $\mathrm{Rh} / \mathrm{ZrO}{ }_{2}$ catalyst for steam reforming of propane. 


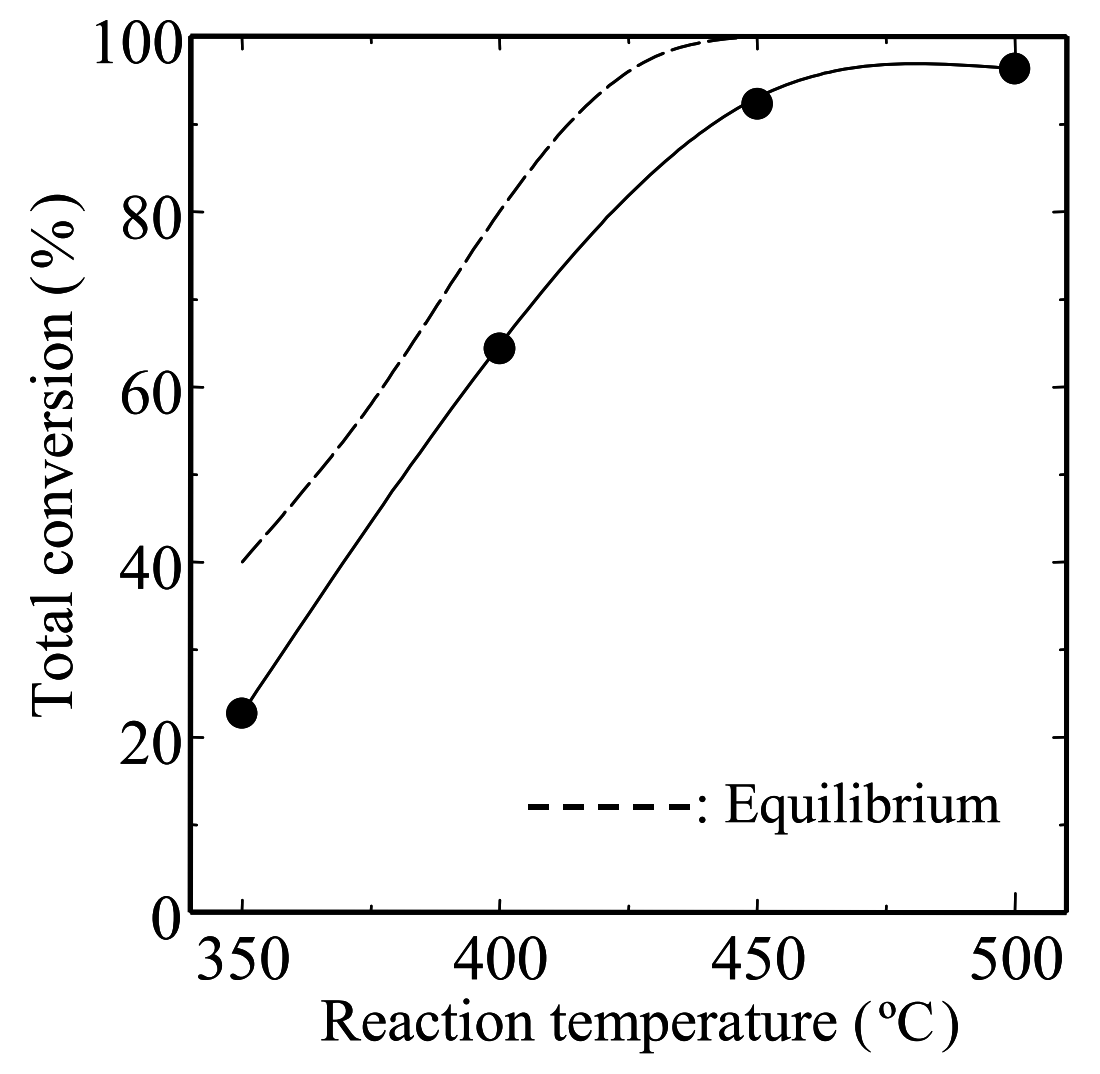

Fig.12 Reforming activity of propane for the plate-type $\mathrm{Rh} / \mathrm{ZrO}_{2}$ catalysts prepared by twice-dipping treatment. 

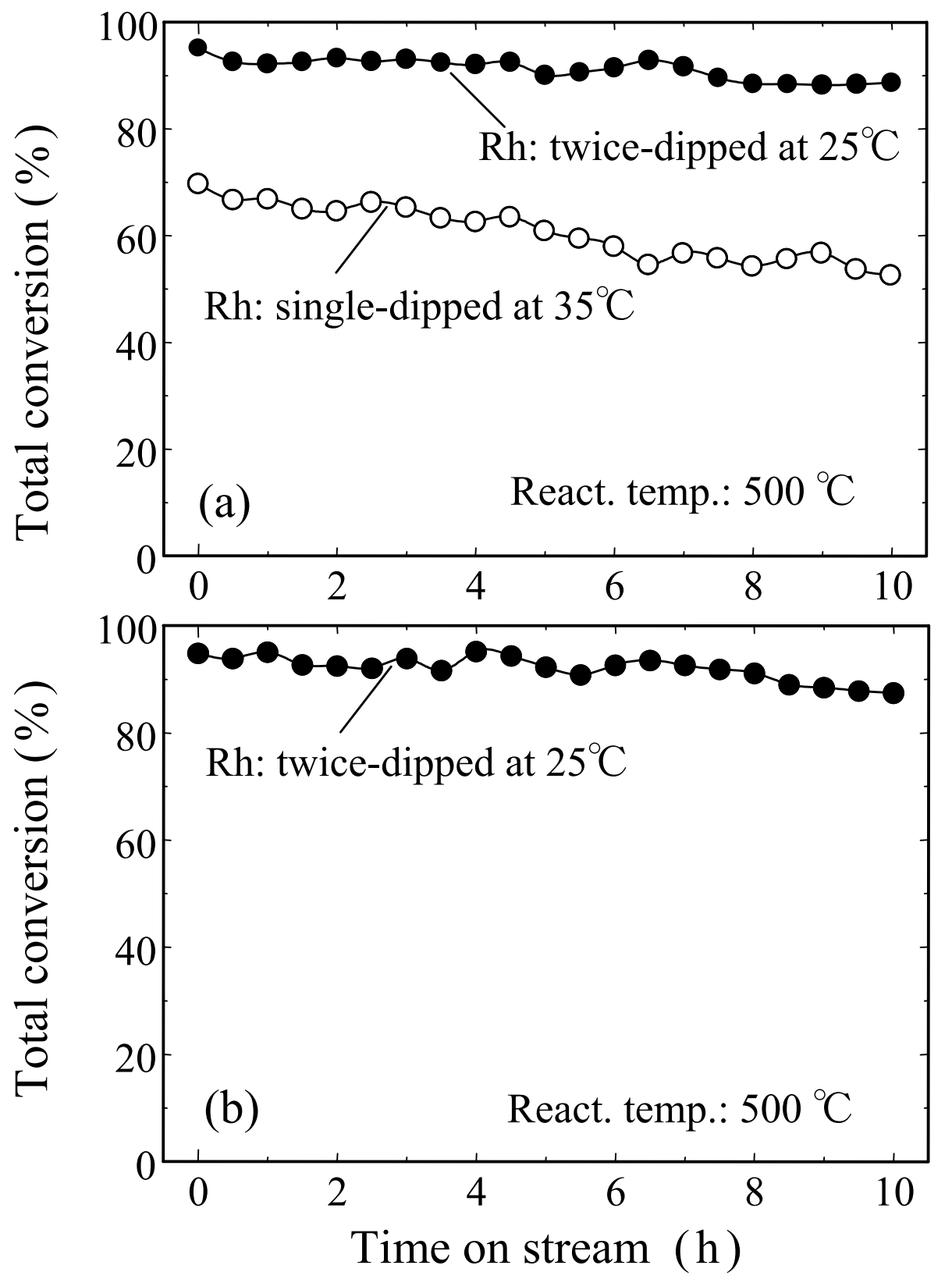

Fig.13 Durability performance of the plate-type $\mathrm{Rh} / \mathrm{ZrO}{ }_{2}$ catalyst for steam reforming of (a) n-butane and (b) propane. 
Table1 Rhodium state on zirconia substrate supported by different dipping condition.

\begin{tabular}{lcccc}
\hline & \multicolumn{4}{c}{ Supported condition; bath temperature and dipped number } \\
\cline { 2 - 5 } & $\begin{array}{l}25^{\circ} \mathrm{C}, \\
\text { single }\end{array}$ & $\begin{array}{l}25^{\circ} \mathrm{C}, \\
\text { twice }\end{array}$ & $\begin{array}{l}35^{\circ} \mathrm{C}, \\
\text { single }\end{array}$ & $\begin{array}{l}40^{\circ} \mathrm{C}, \\
\text { single }\end{array}$ \\
\hline $\begin{array}{l}\text { Metallic surface } \\
\text { area }\left(\mathrm{m}^{2} / \mathrm{g}\right)\end{array}$ & 0.9 & 1.7 & 1.5 & 1.6 \\
\hline $\begin{array}{l}\text { Mean particle } \\
\text { size (nm) }\end{array}$ & 13.5 & 16.8 & 23.9 & 172 \\
\hline $\begin{array}{l}\text { Metal dispersion } \\
(\%)\end{array}$ & 8.2 & 6.5 & 4.6 & 0.6 \\
\hline $\begin{array}{l}\text { Supported weight } \\
(\mathrm{wt} \%)\end{array}$ & 2.6 & 5.6 & 7.9 & 59.2 \\
\hline
\end{tabular}

